\title{
Changes in Serum Amino Acid Content and Dopamine- $\beta$-Hydroxylase Activity and Brain Neurotransmitter Interaction in Cats Fed Casein with or without Gluten or Gliadin
}

\author{
Louise Thibault, ${ }^{1, *}$ Jean-François Coulon, ${ }^{2}$ Claude Roberge, ${ }^{3}$ \\ André Dontigny, ${ }^{3}$ Nathalie Tremblay,${ }^{3}$ and Andrée G. Roberge ${ }^{3}$ \\ ${ }^{1}$ School of Dietetics and Human Nutrition, Macdonald College, \\ McGill University, Montréal, Canada, H9H $4 B 7$ \\ ${ }^{2}$ Laboratoire de Biochimie, Faculté des Sciences, \\ Université d'Angers, France \\ ${ }^{3}$ Laboratoire de Neurochimie et de Nutrition, F.S.A.A., \\ Pavillon Paul-Comtois, Université Laval, \\ Ste-Foy, Québec, Canada, GIK $7 P 4$
}

(Received October 26, 1987)

Summary Adult cats adapted to a semi-purified casein diet were used to study the effects of chronic doses of gluten or gliadin administered per os for 16 consecutive days, for a total of $700 \mathrm{mg}$ per $\mathrm{kg}$ per day, on various blood and brain parameters. The ad libitum food intake, serum amino acid content, brain, adrenal, and serum dopamine- $\beta$-hydroxylase activity, and cerebral GABAergic, cholinergic, dopaminergic, noradrenergic, and serotonergic metabolism of cats fed casein gluten or gliadin were studied. In the brain, the wheat proteins favored mesolimbic and nigrostriatal dopaminergic pathways and decreased the choline acetyltransferase and glutamic acid decarboxylase activities in these pathways thus suggesting an interaction between the corresponding neurotransmitters. The decreased food intake in cats fed gluten or gliadin was paralleled by an increased noradrenaline, dopamine, and serotonin contents in the brainstem areas. In treated cats the adrenal and serum dopamine- $\beta$-hydroxylase activities were decreased whereas this enzyme activity in the brain remained normal. The ratio of serum total tryptophan or tyrosine to the sum of six neutral amino acids were significantly decreased and inversely correlated with serotonin and catecholamine contents in the brain. Biochemical peripheral and cerebral disturbances observed following chronic gluten or gliadin administration

*To whom correspondence should be addressed. 
could provide some basis for correlated behavioral properties of wheat peptides.

Key Words: gluten-gliadin, neurotransmitters, amino acids, enzymes, cat

Early studies have described dietary proteins, namely, gluten and its major component gliadin, as pathogenic factors involved in coeliac disease [1] as well as in psychiatric disorders in man [2]. In commenting on the similarities between symptoms of schizophrenia and those that occur in coeliac disease, Dohan and Grasberger [3] and Dohan et al. [4] reported that schizophrenic patients on a cerealfree and milk-free diet improved at a significantly faster rate than other patients. An uncontrolled trial in 16 cases of schizophrenia revealed an improvement of the symptoms in two of them on a low gluten diet [5]. On the other hand, no behavioral changes were observed after gluten challenge in chronic cases of schizophrenia who remained on a cereal-free and milk-free diet, according to the study of Potkin et al. [6].

It has been suggested that wheat proteins have an exacerbating effect on schizophrenic patients by diminishing the response to neuroleptics [7], whereas Osborne et al. [8] did not find any evidence that gluten interferes with the absorption of neuroleptic medication. An improvement of behavioral status was somewhat demonstrated in adult coeliac patients fed a gluten-free diet [9].

Wheat proteins were found to exert their biological activity through large molecules of gluten derivatives that can reach the brain in schizophrenia symptomproducing amounts $[10,11]$. Exorphins (exogenous peptides derived from gluten) were suggested to be responsible for the relationship between wheat gluten and schizophrenia $[11,12]$.

The purposes of the present work were to use two types of wheat proteins, gluten and gliadin, administered chronically to normal cats in order to compare the dietary effects on 1 ) the body weight and food and water intakes; 2 ) the serum dopamine- $\beta$-hydroxylase (DBH) activity and neutral amino acids concentrations; 3) the adrenal DBH activity, 4) the brain choline acetyltransferase (ChAT), glutamic acid decarboxylase (GAD), and DBH activities, and the serotonin (5-HT), 5hydroxyindoleacetic acid (5-HIAA), noradrenaline (NA) and dopamine (DA) content in 10 brain areas, and to analyse the data in the light of the biochemical mechanisms associated with schizophrenia.

\section{MATERIALS AND METHODS}

Animals. Twenty-four adult mongrel cats of both sexes, initially weighing $2.94 \pm 0.08 \mathrm{~kg}$, were adapted to environmental conditions for at least three weeks and were judged healthy by a veterinarian. They were housed in individual stainless steel cages in a room controlled at constant temperature $\left(21^{\circ} \mathrm{C}\right)$ and humidity 
$(55 \%)$ with fluorescent lights and background music from 06:00 to 18:00 h. The experiment was conducted during the spring.

Biochemical procedures. Cats were guillotined without anesthesia between 08:00 and 11:30 h. Adrenals, liver, and brain were rapidly set aside and the following brain structures dissected out: the neostriatum, thalamus, hypothalamus, piriform lobe, hippocampus, the ventral and dorsal parts of the mesencephalon (Mes), and the respective raphe nuclei of the Mes, pons and medulla. Blood was collected and centrifuged for $15 \mathrm{~min}$ at $2,500 \mathrm{rpm}$ in a refrigerated $\left(4^{\circ} \mathrm{C}\right)$ Sorvall $\mathrm{RC}-5 \mathrm{~B}$ to separate the serum, which was then stored at $-60^{\circ} \mathrm{C}$. 5-HT, 5-HIAA, NA, and DA were isolated on Sephadex G-10 as described by Early and Leonard [13]. 5-HT and 5-HIAA were determined according to Curzon and Green [14]. NA was oxidized using the technique of Maickel et al. [15], whereas DA was determined according to the method of Welch and Welch [16]. Recoveries of 5-HT, 5-HIAA, NA, and DA were $90 \pm 3 \%, 83 \pm 4 \%, 91 \pm 4 \%$, and $87 \pm 4 \%$, respectively. All estimates were corrected for losses.

Enzyme measurement. Brain ChAT activity was measured according to the method described by Dontigny [17]. Results are expressed in nmol of acetylcholine formed $\cdot \mathrm{h}^{-1} \cdot \mathrm{mg}$ protein ${ }^{-1}$. Brain, adrenal, and serum DBH activities were determined by the method of Kato et al. [18] as modified by Roberge and Charbonneau [19]. Results are expressed in $\mathrm{nmol}$ of octopamine formed $\cdot \mathrm{h}^{-1} \cdot \mathrm{g}$ protein ${ }^{-1}$, or per total wet weight of adrenals or $\mathrm{ml}$ of serum.

Brain GAD activity was measured according to a radiochemical method described by Kravitz et al. [20]. Results are expressed in nmol of $\gamma$-aminobutyric acid (GABA) formed $\cdot \mathrm{h}^{-1} \cdot \mathrm{mg}$ of protein ${ }^{-1}$.

Protein determination. Protein concentrations were measured by the method of Bradford [21] using bovine serum albumin as standard.

Amino acid determination. Four hundred microliter of serum and $400 \mu \mathrm{l}$ of dry $5 \%$ sulfosalicylic acid were stirred together for $5 \mathrm{~min}$, refrigerated $1 \mathrm{~h}$ at $4{ }^{\circ} \mathrm{C}$ and then centrifuged for $15 \mathrm{~min}$ in a Sorvall centrifuge (RC-5B) at 2,500 rpm. Two hundred microliter of the supernatant diluted $1: 1$ with $\mathrm{Li}-\mathrm{S}$ buffer and filtered through a Millipore filter $(0.22 \mu \mathrm{m})$ was used for the analysis. The amino acid analysis was performed with a Beckman amino acid analyzer (Model 6300, Beckman Instruments, Palo Alto, CA) to measure the following amino acids: arginine, cystine, glycine, histidine, isoleucine, leucine, lysine, tyrosine, phenylalanine, valine, threonine, tryptophan, glutamic acid, and methionine. The instrument was calibrated with a standard mixture of 22 amino acids $(2.5 \mu \mathrm{mol} / \mathrm{ml})$, including tryptophan and ornithine. Results are expressed in $\mu \mathrm{mol} / 100 \mathrm{ml}$ of serum. The same method was used to measure the amino acid content of casein, gluten, and gliadin.

Diet and wheat proteins administration. The semi-purified casein diet was formulated to meet nutrient requirements of cats as specified by the National Academy of Sciences, Canada [22]. The requirements were $28 \%$ for protein and $9 \%$ for fat including two essential fatty acids (linoleic and arachidonic acids); and the caloric needs were $70 \mathrm{kcal}$ per $\mathrm{kg}$ of body weight for inactive adult cats. To 
meet the nutritional requirements for cats, the daily dietary ration (dry weight) was $50 \mathrm{~g}$. In diets, the source of fat was corn oil to fulfill the requirements for linoleic and arachidonic acids. Table 1 shows the percentage and the quantity ( $g$, dry weight) of nutrients in the semi-purified diet. Food and tap water were provided ad libitum.

Six cats were used as controls, and 11 and 7 cats received $700 \mathrm{mg}$ per $\mathrm{kg}$ per day of gluten and gliadin, respectively. Both gluten and gliadin were administered orally in gelatin capsules while controls received empty capsules at the same time. The daily dose was fractioned and administered at 4-h intervals for 16 consecutive days. On the 17 th day, cats received the last dose at 10-min intervals and were sacrificed $1 \mathrm{~h}$ later with control cats interspersed between treated animals.

Statistical analysis. Mean, standard deviation, standard error of the mean (SEM), and Student's $t$-test were calculated according to Snedecor and Cochran [23].

Chemicals. 5-HT (creatinine sulfate complex), 5-HIAA (dicyclohexylammonium salt), NA (DL-arterenol $\mathrm{HCl}$ ), DA (3-hydroxytyramine $\mathrm{HCl}$ ), tyramine,

Table 1. Composition of diets (dry weight). ${ }^{\text {a }}$

\begin{tabular}{|c|c|c|c|}
\hline \multicolumn{4}{|c|}{ Casein diet $(\%)$} \\
\hline Protein & & & 30.7 \\
\hline Corn oil & & & 10.0 \\
\hline Corn starcl & & & 23.9 \\
\hline Sucrose & & & 19.2 \\
\hline Alphacel & & & 5.0 \\
\hline Salt mix & & & 10.0 \\
\hline Vitamin $\mathrm{m}$ & & & 1.1 \\
\hline $\mathrm{CHO}$ : $\mathrm{pr}$ & & & 1.4 \\
\hline Energy den & & & 3.9 \\
\hline Amino acids ${ }^{c}$ & Casein & $\begin{array}{c}\text { Gluten } \\
\left.\text { (g per } 16 \mathrm{~g} \mathrm{~N}_{\mathrm{N}}\right)\end{array}$ & Gliadin \\
\hline Arginine & 3.45 & 3.09 & 2.50 \\
\hline Cystine & 1.97 & 2.15 & 1.63 \\
\hline Glycine & 1.89 & 3.49 & 2.07 \\
\hline Histidine & 3.02 & 2.08 & 2.43 \\
\hline Isoleucine & 3.58 & 2.13 & 4.17 \\
\hline Leucine & 9.07 & 6.57 & 7.08 \\
\hline Tyrosine & 5.07 & 3.02 & 3.13 \\
\hline Phenylalanine & 4.54 & 5.79 & 5.55 \\
\hline Valine & 4.57 & 2.71 & 3.87 \\
\hline Methionine & 1.91 & 1.32 & 0.71 \\
\hline Lysine & 7.43 & 1.57 & 0.63 \\
\hline Threonine & 3.97 & 2.44 & 1.72 \\
\hline Tryptophan & 0.93 & 0.47 & 0.68 \\
\hline Glutamic acid & 22.30 & 38.20 & 41.00 \\
\hline
\end{tabular}

${ }^{a}$ Prepared in our laboratory with purified casein ( $99 \%$ protein). b Total carbohydrates $(\mathrm{CHO})$ to protein ratio. ${ }^{\mathrm{c}}$ Amino acids from gluten, gliadin, and casein were determined by the method described in the Materials and Methods section. 
sodium-m-periodate, fumaric acid, pargyline $\mathrm{HCl}$, ascorbic acid, octopamine, sodium-m-periodate, catalase, Sephadex G-10 and Dowex 50W-4X were purchased from Sigma Chemical Company (St. Louis, MO). Trichloroacetic acid, sodium bisulfite, and monobasic and dibasic sodium phosphate were obtained from Fisher Scientific (Ste-Foy, Québec). Sodium acetate and N-ethyl-maleimide were purchased from BDH (Ville St. Laurent, Québec). Columns (glass-barrel ECONO-columns, i.d. $7 \times 40 \mathrm{~mm}$ ) were obtained from Bio-Rad Laboratories Ltd. (Richmond, CA). Empty gelatin capsules (No. 0) were from Parke, Davis Ltd. (Brockville, Ontario). Casein, salt mix, vitamin mix and alphacel were supplied by ICN Nutritional Biochemicals (Montréal, Québec). Wheat gluten (WHETPRO-80) was from Industrial Grain Products Ltd. (Montréal, Québec) and gliadin (crude from wheat gluten) from Sigma Chemical Company, (St. Louis, MO). Bovine serum albumin was purchased at ICN Pharmaceuticals Inc. (Cleveland, OH). Li-S buffer and the 22 amino acids used as standard were purchased from Beckman Company (Palo Alto, CA). $\left[{ }^{14} \mathrm{C}\right]$ Choline, $\left[{ }^{14} \mathrm{C}\right]$ acetylcoenzyme A, $\left[{ }^{14} \mathrm{C}\right]$ glutamic acid, and $\left[{ }^{14} \mathrm{C}\right] \gamma^{-}$ aminobutyric acid were purchased from New England Nuclear, Canada.

\section{RESULTS}

Since no significant difference was found between results obtained in cats fed casein diet with gluten or gliadin, most results obtained from these treated groups were pooled. The initial body weight of control and treated cats was not significantly different from that at the end of the 16-day period. On the other hand, the adrenal weight was significantly higher in cats receiving gluten or gliadin than in control cats (controls, $231 \pm 19 \mathrm{mg}$; treated, $273 \pm 10 \mathrm{mg} ; p<0.05$ ). The mean daily food (dry weight) and water intake were significantly higher in controls than in cats receiving gluten or gliadin (food: controls, $32 \pm 1 \mathrm{~g}$; treated, $23 \pm 1 \mathrm{~g} ; p<0.01$; water: control, $73 \pm 2 \mathrm{ml}$; treated, $61 \pm 2 \mathrm{ml} ; p<0.01$ ).

Data presented in Table 2 show the dietary intake and the serum concentration of neutral amino acids in control and gluten- and gliadin-treated cats. Cats fed the casein diet with gluten or gliadin maintained their serum neutral amino acid content comparable to controls, except for isoleucine and methionine, which were significantly increased $(p<0.05)$, and for total tryptophan, which was decreased $(p<0.05)$ (Table 2). The total amount of the seven neutral amino acids was slightly higher in the serum of cats fed the casein diet with gluten or gliadin than in the serum of cats fed the casein diet alone. The ratio of total tryptophan to the sum of the six neutral amino acids (6 NAA) was significantly lower $(p<0.01)$ in cats fed casein diet with gluten or gliadin than in control cats fed casein, as was the ratio of tyrosine to 6 NAA ratio $(p<0.05)$ (Table 2).

In Table 3, the effects of the wheat proteins, gluten and gliadin, on 5-HT and 5-HIAA concentrations in 10 brain areas are presented. In the gluten and gliadin groups, the 5-HT content was increased in the thalamus $(p<0.05)$, hypothalamus $(p<0.05)$, both dorsal and ventral Mes $(p<0.05)$ and medulla raphe nuclei 
Table 2. Daily dietary intake of neutral amino acids (NAA) and their concentrations in serum of cats fed casein with or without gluten or gliadin.

\begin{tabular}{|c|c|c|c|c|}
\hline \multirow[b]{2}{*}{ Amino acids } & \multicolumn{2}{|c|}{$\begin{array}{l}\text { Dietary intake a } \\
\quad(\mathrm{mg} / \text { day })\end{array}$} & \multicolumn{2}{|c|}{$\begin{array}{l}\text { Serum concentration }(\overline{\mathrm{X}} \pm \mathrm{SEM}) \\
(\mu \mathrm{mol} / 100 \mathrm{ml})\end{array}$} \\
\hline & $\begin{array}{l}\text { Casein } \\
(6)\end{array}$ & $\begin{array}{l}\text { Casein } \\
\text { plus } \\
\text { gluten } \\
\text { or } \\
\text { gliadin } \\
\text { (13) }\end{array}$ & $\begin{array}{c}\text { Casein } \\
\text { (6) }\end{array}$ & $\begin{array}{l}\text { Casein } \\
\text { plus } \\
\text { gluten } \\
\text { or } \\
\text { gliadin } \\
\text { (13) }\end{array}$ \\
\hline Valine & 277 & 341 & $33.5 \pm 2.6$ & $36.2 \pm 3.3$ \\
\hline Isoleucine & 217 & 280 & $13.0 \pm 0.8$ & $16.4 \pm 1.0^{*}$ \\
\hline Leucine & 550 & 681 & $24.1 \pm 2.2$ & $26.1 \pm 2.2$ \\
\hline Tyrosine & 307 & 366 & $9.8 \pm 0.7$ & $10.2 \pm 0.6$ \\
\hline Phenylalanine & 275 & 383 & 12. $1 \pm 1.0$ & $12.5 \pm 0.5$ \\
\hline Methionine & 116 & 135 & $5.9 \pm 0.4$ & $7.7 \pm 0.5^{*}$ \\
\hline Total tryptophan & 56 & 68 & $6.0 \pm 0.6$ & $4.0 \pm 0.4^{*}$ \\
\hline Total tryptophan/6 NAA ratio $b$ & 0.032 & 0.031 & $0.059 \pm 0.003$ & $0.038 \pm 0.004^{* *}$ \\
\hline Tyrosine/ 6 NAA ratio $^{c}$ & 0.206 & 0.194 & $0.116 \pm 0.003$ & $0.096 \pm 0.006^{*}$ \\
\hline
\end{tabular}

a The dietary intake was calculated from the diet amino acids (Table 1) and the daily food intake. Figures in parentheses indicate the number of cats. b Valine, isoleucine, leucine, tyrosine, phenylalanine, methionine. $\quad{ }^{\mathrm{c}}$ Valine, isoleucine, leucine, phenylalanine, methionine, total tryptophan. $* p<0.05 ; * * p<0.01$.

Table 3. Brain 5-HT and 5-HIAA content in cats fed casein with (treated cats) or without (controls) gluten or gliadin. ${ }^{a}$

\begin{tabular}{lccccc}
\hline \multirow{2}{*}{ Structures } & \multicolumn{2}{c}{5 -HT } & & \multicolumn{2}{c}{ 5-HIAA } \\
\cline { 2 - 3 } \cline { 5 - 6 } & $c$ Controls & Treated cats & & $\begin{array}{c}\text { Controls } \\
(6)\end{array}$ & $\begin{array}{c}\text { Treated cats } \\
(17)\end{array}$ \\
\hline Neostriatum & $1.39 \pm 0.11$ & $1.54 \pm 0.12$ & & $1.04 \pm 0.07$ & $1.02 \pm 0.03$ \\
Thalamus & $0.90 \pm 0.05$ & $1.19 \pm 0.07^{*}$ & & $1.27 \pm 0.08$ & $1.32 \pm 0.04$ \\
Hypothalamus & $2.44 \pm 0.23$ & $2.98 \pm 0.11^{*}$ & & $1.08 \pm 0.11$ & $1.37 \pm 0.06^{*}$ \\
Hippocampus & $1.01 \pm 0.03$ & $1.04 \pm 0.04$ & & $0.96 \pm 0.08$ & $0.97 \pm 0.03$ \\
Piriform lobe & $0.98 \pm 0.11$ & $0.97 \pm 0.05$ & & $1.29 \pm 0.11$ & $1.17 \pm 0.06$ \\
Dorsal Mes & $1.86 \pm 0.13$ & $2.32 \pm 0.12^{*}$ & & $1.61 \pm 0.10$ & $1.87 \pm 0.11$ \\
Ventral Mes & $0.78 \pm 0.05$ & $0.97 \pm 0.05^{*}$ & & $0.40 \pm 0.04$ & $0.40 \pm 0.03$ \\
Raphe nuclei (Mes) & $2.79 \pm 0.12$ & $2.77 \pm 0.14$ & & $2.29 \pm 0.22$ & $1.81 \pm 0.09^{*}$ \\
Raphe nuclei (Pons) & $1.35 \pm 0.10$ & $1.18 \pm 0.07$ & & $1.80 \pm 0.17$ & $1.50 \pm 0.09$ \\
Raphe nuclei (Medulla) & $1.46 \pm 0.12$ & $1.85 \pm 0.10^{*}$ & & $1.36 \pm 0.12$ & $1.07 \pm 0.05^{*}$ \\
\hline
\end{tabular}

${ }^{\text {a }}$ Results are expressed in $\mu \mathrm{g}$ of 5 -HT or 5-HIAA per $\mathrm{g}$ tissue $(\overline{\mathrm{X}} \pm \mathrm{SEM})$. Figures in parentheses indicate the number of animals used. ${ }^{*} p<0.05$.

$(p<0.05)$. A significant rise in 5-HIAA level was found in the hypothalamus $(p<0.05)$, whereas the 5-HIAA content was decreased in both the Mes and medulla raphe nuclei $(p<0.05)$.

In cats fed gluten or gliadin, the NA content was decreased in the neostriatum $(p<0.01)$, thalamus $(p<0.05)$, and piriform lobe $(p<0.05)$, but increased in the 
Table 4. Brain NA and DA content in cats fed casein with or without gluten or gliadin. ${ }^{\mathrm{a}}$

\begin{tabular}{lccccc}
\hline \multirow{2}{*}{ Structures } & \multicolumn{2}{c}{ NA } & & \multicolumn{2}{c}{ DA } \\
\cline { 2 - 3 } \cline { 5 - 6 } & $\begin{array}{c}\text { Controls } \\
(6)\end{array}$ & $\begin{array}{c}\text { Treated cats } \\
(16)\end{array}$ & & $\begin{array}{c}\text { Controls } \\
(6)\end{array}$ & $\begin{array}{c}\text { Treated cats } \\
(16)\end{array}$ \\
\hline Neostriatum & $0.30 \pm 0.02$ & $0.24 \pm 0.01^{* *}$ & & $12.44 \pm 0.94$ & $12.20 \pm 0.40$ \\
Thalamus & $0.33 \pm 0.03$ & $0.25 \pm 0.02^{*}$ & & $0.20 \pm 0.03$ & $0.20 \pm 0.01$ \\
Hypothalamus & $1.87 \pm 0.22$ & $1.84 \pm 0.14$ & & $0.18 \pm 0.01$ & $0.23 \pm 0.01^{* *}$ \\
Hippocampus & $0.20 \pm 0.01$ & $0.18 \pm 0.01$ & & $0.21 \pm 0.04$ & $0.17 \pm 0.01$ \\
Piriform lobe & $0.52 \pm 0.02$ & $0.40 \pm 0.03^{*}$ & & $0.41 \pm 0.02$ & $0.43 \pm 0.03$ \\
Dorsal Mes & $0.42 \pm 0.04$ & $0.58 \pm 0.04^{*}$ & & $0.36 \pm 0.04$ & $0.41 \pm 0.02$ \\
Ventral Mes & $0.25 \pm 0.02$ & $0.21 \pm 0.02$ & & $0.63 \pm 0.01$ & $0.72 \pm 0.02^{*}$ \\
Raphe nuclei (Mes) & $0.54 \pm 0.08$ & $0.58 \pm 0.03$ & & $0.21 \pm 0.03$ & $0.34 \pm 0.03^{*}$ \\
Raphe nuclei (Pons) & $0.68 \pm 0.06$ & $0.87 \pm 0.05^{*}$ & & $0.28 \pm 0.04$ & $0.32 \pm 0.03$ \\
Raphe nuclei (Medulla) & $0.28 \pm 0.05$ & $0.72 \pm 0.06^{* * *}$ & & $0.29 \pm 0.02$ & $0.26 \pm 0.02$ \\
\hline
\end{tabular}

${ }^{\text {a }}$ Results are expressed in $\mu \mathrm{g}$ of NA or DA per $\mathrm{g}$ of tissue $(\overline{\mathrm{X}} \pm \mathrm{SEM})$. Figures in parentheses indicate the number of animals used. ${ }^{*} p<0.05 ;{ }^{*} p<0.01 ; * * * p<0.001$.

Table 5. Brain choline acetyltransferase (ChAT) activity and adrenal, serum and brain dopamine- $\beta$-hydroxylase (DBH) activity in cat fed casein with or without gluten or gliadin.

\begin{tabular}{|c|c|c|c|c|c|}
\hline \multirow{2}{*}{ Structures } & \multicolumn{5}{|c|}{$\mathrm{ChAT}^{\mathrm{a}}$} \\
\hline & \multicolumn{2}{|l|}{ Controls } & Gluten & \multicolumn{2}{|c|}{ Gliadin } \\
\hline Neostriatum & \multicolumn{2}{|l|}{$50 \pm 4$} & $47 \pm 5$ & \multicolumn{2}{|c|}{$30 \pm 5^{*}$} \\
\hline Piriform lobe & \multicolumn{2}{|l|}{$49 \pm 10$} & $44 \pm 8$ & \multicolumn{2}{|c|}{$39 \pm 4$} \\
\hline Thalamus & \multicolumn{2}{|l|}{$6.2 \pm 0.3$} & $5.4 \pm 0.7$ & \multicolumn{2}{|c|}{$4.7 \pm 0.4^{*}$} \\
\hline Ventral Mes & \multicolumn{2}{|l|}{$10.7 \pm 0.8$} & $6.7 \pm 0.8^{* *}$ & \multicolumn{2}{|c|}{$7.0 \pm 0.7^{* *}$} \\
\hline \multirow{2}{*}{ Structures } & \multicolumn{5}{|c|}{$\mathrm{DBH}^{\mathrm{b}}$} \\
\hline & \multicolumn{2}{|c|}{ Controls } & & \multicolumn{2}{|c|}{ Treated cats } \\
\hline Adrenal & $81.1 \pm 4.6$ & (6) & & $66.7 \pm 3.8^{*}$ & (12) \\
\hline Serum & $18.5 \pm 1.7$ & (8) & & $12.0 \pm 1.5^{* *}$ & (12) \\
\hline Hypothalamus & $5.5 \pm 0.16$ & (6) & & $5.3 \pm 0.40$ & (12) \\
\hline Thalamus & $5.1 \pm 0.22$ & (6) & & $4.7 \pm 0.29$ & $(17)$ \\
\hline Raphe nuclei (Mes) & $3.3 \pm 0.27$ & (6) & & $3.5 \pm 0.19$ & $(12)$ \\
\hline
\end{tabular}

${ }^{a}$ Results are expressed in nmol of acetylcholine formed $\cdot \mathrm{h}^{-1} \cdot \mathrm{mg}$ of protein ${ }^{-1}(\overline{\mathrm{X}} \pm \mathrm{SEM})$. The number of cats is 6 . b Results are expressed in nmol of octopamine formed-total weight (adrenal) $)^{-1} \cdot \mathrm{h}^{-1} \cdot \mathrm{ml}$ of serum ${ }^{-1} \cdot \mathrm{h}^{-1} \cdot \mu \mathrm{g}$ of protein (brain tissues) $)^{-1} \cdot \mathrm{h}^{-1}(\overline{\mathrm{X}} \pm \mathrm{SEM})$. Figures in parentheses indicate the number of cats. ${ }^{*} p<0.05 ;{ }^{*} p<0.01$.

dorsal Mes $(p<0.05)$ and in the pons and medulla raphe nuclei $(p<0.05$ and $p<0.001$, respectively), when the results were compared with the respective control values (Table 4). The wheat proteins produced an increased DA content in the hypothalamus $(p<0.01)$, ventral Mes $(p<0.05)$, and Mes raphe nuclei $(p<0.05)$.

Table 5 presents the variations in DBH activity in the adrenal, serum, hypothalamus, thalamus, and raphe nuclei in control and treated cats and the effects of gluten and gliadin on ChAT activity in different brain areas. In the adrenal 
$(p<0.05)$ and serum $(p<0.01)$ of treated cats, DBH activity was significantly decreased, whereas no significant change in DBH activity was observed in the brain structures examined. A significant decrease in ChAT activity was observed in the neostriatum $(p<0.01)$ and thalamus $(p<0.05)$ in cats fed the casein diet with gliadin but not in cats fed that with gluten. However, a significant decrease in ChAT activity was observed in the ventral Mes in both groups of cats $(p<0.01)$.

GAD activity measured in the ventral Mes was significantly decreased in cats fed the casein diet with gliadin $\left(4.25 \pm 0.32 \mathrm{nmol}\right.$ of GABA formed $\cdot \mathrm{h}^{-1} \cdot \mathrm{mg}$ protein $^{-1}$ $p<0.05)$ when compared with the activity in cats fed the casein diet containing gluten or the casein diet alone $(5.6 \pm 0.37$ and $5.6 \pm 0.42 \mathrm{nmol}$ of GABA formed. $\mathrm{h}^{-1} \cdot \mathrm{mg}$ protein $^{-1}$, respectively).

\section{DISCUSSION}

The present study has demonstrated that wheat proteins, gluten or gliadin, given for 16 consecutive days 1) diminish daily food and water intakes; 2) affect differently monoaminergic systems in cat brain, dissociating the brainstem areas from the diencephalic areas; 3) decrease the brain GAD and ChAT activities, leaving unaffected the brain DBH activity; 4) decrease the adrenal and serum DBH activity; and 5) increase the serum isoleucine and methionine concentrations but decrease the serum total tryptophan content.

A significantly increased 5-HT, NA, and DA content in the brainstem areas was observed in cats fed the casein diet with gluten or gliadin for 16 consecutive days. The high content of biogenic amines in the brainstem areas could be associated with a reduced turnover rate or at least a lower release of these amines, as reported by Hery et al. [24] and as indicated by the significantly increased ratio of 5-HT to 5-HIAA observed in the medulla raphe nuclei in treated cats (controls, $1.19 \pm 0.13$; treated, $1.67 \pm 0.11 ; p<0.05)$. Moreover, to this increased biogenic amine content corresponds a decrease in ChAT and GAD activities in the brainstem areas, demonstrating a biochemical balance between the biogenic amine group (5-HT, DA, and NA) and the neurotransmitters, acetylcholine and GABA.

It is obvious to pinpoint that among the biogenic amines involved in the functioning of the brainstem reticular mechanism, NA and 5-HT are the most frequently associated with either arousal [25, 26] or hunger and satiety [27] or the state of chronic hyperarousal observed in schizophrenic patients [28]. In the present study, significant 5-HT and NA increases were found in the medulla raphe nuclei of treated cats, which brain area is involved in the regulation of hunger and satiation mechanisms. In fact, the disturbed NA and 5-HT content in the medulla raphe nuclei might be related to the simultaneous decrease in food and water intakes observed in cats fed the casein diet with gluten or gliadin. Moreover, the present results suggest that gluten and gliadin may act as anorexigenic agents in the same way as amphetamines in man and animals [29-31], potentiating the mesolimbic dopaminergic system in the central nervous system (CNS). In this respect, appetite 
suppression in coeliac and schizophrenic patients is often observed in the course of the evolution of these pathologies [32].

The present data have demonstrated that all biogenic amines were increased in cell bodies of the brainstem of treated cats, whereas an inverse relationship was observed between NA and 5-HT content in the diencephalic areas. Indeed, to a significant decrease in the diencephalic NA content corresponded a significant increase in 5-HT level, dissociating the physiological behavior of these amines on a neuroanatomical basis as previously reported by Roberge [33] and Roberge et al. [34]. On the other hand, DA and NA have been suggested to be dynamically and functionally interrelated in different behavioral situations and in schizophrenia [35-37]. Numerous biochemical studies on human post-mortem brains from schizophrenics and from patients with related psychotic conditions have shown increased central DA concentrations as well as decreased ChAT and GAD activities [38-40]. In the present study, the low ChAT activity observed in the ventral Mes, neostriatum and thalamus, and the low GAD activity associated with the increased DA content in the ventral Mes of treated cats provide strong similarities with the previous studies done in human post-mortem brains from schizophrenics.

In cats fed the casein diet with gluten or gliadin, a lower DA utilization or release than in controls is suggested by the decreased NA level in the neostriatum as well as by an increased DA : NA ratio in the neostriatum and Mes raphe nuclei (controls, 39.1 \pm 4.4 ; treated, $51.3 \pm 2.5 ; p<0.05$ : controls, $0.43 \pm 0.04$; treated, $0.65 \pm 0.06 ; p<0.05$ : respectively), and parallels the increased DA concentration found in the ventral Mes containing the substantia nigra dopaminergic cell bodies that send numerous projections to the caudate nucleus and putamen [41, 42]. These results might be indicative of an enhanced neuronal activity in the nigrostriatal pathway and are consistent with the DA hypothesis of schizophrenia [43].

The present findings demonstrate in cats fed the casein diet with gluten or gliadin (a) decreased content of serum total tryptophan; (b) lowered ratio of serum total tryptophan to $6 \mathrm{NAA}$; (c) increased content of brain 5-HT and DA; (d) decreased ratio of serum tyrosine to 6 NAA, and (e) increased or decreased content of brain NA. According to these data, a low ratio of serum total tryptophan to 6 NAA corresponds to a high 5-HT content in the brainstem and diencephalic areas, whereas a low ratio of serum tyrosine to 6 NAA corresponds to a high DA content in brainstem and diencephalic areas but to a high NA content in the brainstem areas and to a low NA level in diencephalic areas. The present data tend to demonstrate that under chronic dietary conditions, serum neutral amino acid ratios do not seem to govern the overall CNS biogenic amine level and the differentiated neuroanatomical pathways present in the diencephalon and brainstem areas have to be taken into consideration. This assumption is in agreement with several studies [34, 44-46] that have attempted to define the interactions between the neurotransmitters on a neuroanatomical basis.

The present work also suggests that the nature, quality, and the digestibility

Vol. 4, No. 3, 1988 
of dietary protein affect the dietary intake and that the bioavailability of amino acids in the blood may be related to the composition of essential amino acids in the dietary protein [47]. In fact, in cats fed the casein diet with gluten or gliadin, the wheat proteins could have contributed to the decreased dietary intake because of a lower digestibility of these wheat proteins than of casein itself (net protein utilization: 54.1 and 83.5 for gluten and casein, respectively) [48].

Moreover, some clinical biochemical parameters were also disturbed by the dietary protein treatment, such as the lowered adrenal and serum DBH activities. These data are supported by the recent works of Thibault and Roberge [49, 50] and Roberge and Charbonneau [19], who showed that dietary proteins selectively affect the serum DBH activity in cats adapted to different sources of protein.

In summary, the present work shows that feeding chronic doses of gluten or gliadin, peptides derived from wheat proteins and involved in coeliac disease, produces a disturbance in the biogenic amine equilibrium in different neuroanatomical systems which may provide a partial explanation of some previous studies demonstrating aggravation of schizophrenic symptoms in humans following wheat peptide ingestion as well as behavioral effects related to hunger and satiation mechanisms. In fact, the present data reveal that (1) the quality of the dietary protein source influences the food and water intakes and biochemical blood parameters; (2) the ratio of serum total tryptophan or tyrosine to 6 NAA is not directly correlated with catecholamine and serotonin content in the CNS, and (3) the disturbance in brain biogenic amines induced by chronic ingestion of the wheat peptides, gluten and gliadin, might affect some mechanisms related to hunger and satiation located in the brainstem areas as well as mechanisms underlying some schizophreniform reaction in man, but via brain pathways. It is difficult, however, to conclude that gluten sensitivity is of general relevance in schizophrenia since this disorder is not a homogeneous entity and immunological sensitivity is idiosyncratic [51]. The gluten hypothesis of schizophrenia thus needs to be investigated in very carefully designed studies in which the nutritional approach is considered on the basis of the availability of macro- and micronutrients.

The authors gratefully acknowledge the technical assistance of Ruth Charbonneau and the editorial help of Nicole Seoane, M.Sc. This research was supported by the Natural Sciences and Engineering Research Council of Canada (Studentship to Louise Thibault and grant No. A7946) by CRESAQ and FCAR-équipe, Québec.

\section{REFERENCES}

1. Dicke, W.K. (1980): Coeliakie, een onderzoek de nadelige invloed van sommige graansoorten op de lijder ann coealiakie. M.D. Thesis. University of Utrecht, The Netherlands 1950, in Modern Nutrition in Health and Disease, ed. by Goodhart, R.A., and Shils, M.E., Lea and Febiger, Philadelphia, pp. 912-952.

2. Wallen, R. (1948): Food [aversions in behaviour disorders. J. Consult. Psychol., 12, 310-312.

3. Dohan, F.C., and Grasberger, J.C. (1973): Relapsed schizophrenics: earlier discharge from 
the hospital after cereal-free, milk-free diet. Am. J. Psychiatry, 130, 685-688.

4. Dohan, F.C., Grasberger, J.C., Lowell, F.M., Johnston, H.T., and Arbegast, A.W. (1969): Relapsed schizophrenics: more rapid improvement on a milk and cereal-free diet. $B r . J$. Psychiatry, 115, 595-596.

5. Rice, J.R., Ham, C.H., and Gore, W.E. (1978): Another look at gluten in schizophrenia. Am. J. Psychiatry, 135, 1417-1418.

6. Potkin, S.G., Weinberger, D., Kleinman, J., Nasrallah, H., Luchins, D., Bigelow, L., Linnolia, M., Fischer, S.H., Bjornsson, T.D., Carman, J., Gillin, J.C., and Wyatt, R.J. (1981): Wheat challenge in schizophrenic patients. Am. J. Psychiatry, 138, 1208-1211.

7. Singh, M.M., and Kay, S.R. (1976): Wheat gluten as a pathogenic factor in schizophrenia. Science, 191, 401-402.

8. Osborne, M., Clayton, J.W., Javaid, I., and Davis, J.M. (1982): Lack of effect of a glutenfree diet on neuroleptic blood levels in schizophrenic patients. Biol. Psychiatry, 17, 627-629.

9. Hallert, C., and Sedvall, G. (1983): Improvement in central monoamine metabolism in adult coeliac patients starting a gluten-free diet. Psychol. Med., 13, 267-271.

10. Hemmings, A.A. (1978): The entry into the brain of large molecules derived from dietary protein. Proc. R. Soc. Lond., 200, 175-192.

11. Klee, W.A., Zioudrou, C., and Streaty, R.A. (1978): Exorphins, peptides with opioid activity isolated from wheat gluten and their possible role in the etiology of schizophrenia, in Endorphins in Mental Health Research, ed. by Usdin, E., MacMillan, New Yrok, pp. 209-218.

12. Zioudrou, C., Streaty, R.A., and Klee, W.A. (1979): Opioid peptides derived from food proteins. J. Biol. Chem., 254, 2446-2449.

13. Early, C.E., and Leonard, B.E. (1978): Isolation and assay of noradrenaline, dopamine, 5-hydroxytryptamine and several metabolites from brain tissue using disposable Bio-Rad columns packed with Sephadex G-10. J. Pharmacol. Methods, 1, 67-69.

14. Curzon, G., and Green, A.R. (1970): Rapid method for the determination of 5-hydroxytryptamine and 5-hydroxyindoleacetic acid in small regions of rat brain. Br. J. Pharmacol., 39, 653-655.

15. Maickel, R.P., Cox, R.H., Saillant, S., and Miller, F.P. (1968): A method for the determination of serotonin and norepinephrine in discrete areas of rat brain. Int. J. Neuropharmacol., 7, 275-281.

16. Welch, A.S., and Welch, B.L. (1969): Solvent extraction method for simultaneous determination of norepinephrine, dopamine, serotonin and 5-hydroxyindoleacetic acid in a single mouse brain. Anal. Biochem., 30, 161-179.

17. Dontigny, A. (1984): Etude Cinétique et Mesure de la Choline Acetyltransférase dans le Systéme Nerveux Central du Chat à la Suite d'Interventions Pharmacologiques et Nutritionnelles, Thèse de maîtrise, Université Laval.

18. Kato, T., Hiroski, H., and Nagatsu, T. (1974): A simple and sensitive assay for dopamine- $\beta$ hydroxylase activity by dual-wave-length spectrophotometry. Biochem. Med., 10, 320-328.

19. Roberge, A.G., and Charbonneau, R. (1985): Effects of dietary protein intake and immobilization on plasma dopamine- $\beta$-hydroxylase activity in cats. Nutr. Res., 5, 57-63.

20. Kravitz, E.A., Molinoff, P.B., and Hall, Z.W. (1965): A comparison of the enzymes and substrates of gamma-amino-butyric acid metabolism in lobsters excitatory and inhibitory axons. Proc. Natl. Acad. Sci., USA., 54, 778-782.

21. Bradford, N.M. (1976): A rapid and sensitive method for the quantitation of microgram quantities of protein utilizing the principle of protein-dye binding. Anal. Biochem., 72, 248254.

22. National Academy of Sciences, Canada (1978): Nutrients requirements for domestic animals. No. 13, Nutr. Requir. Cats.

23. Snedecor, G.W., and Cochran, W.G. (1971): Méthodes Statistiques (6th ed.), Paris-Acta, Paris. 
24. Hery, F., Fouer, E., and Glowinski, J. (1972): Daily variations of serotonin metabolism in the rat brain. Brain Res., 43, 445-465.

25. Boakes, J., Bradley, P.B., and Candy, J.M. (1972): A neuronal basis for the alerting action of (+)-amphetamine. Br. J. Pharmacol., 45, 391-403.

26. Bolme, P., Fuxe, K., and Lindbrink, P. (1972): On the function of central catecholamine neurons - their role in cardiovascular and arousal mechanisms. Res. Commun. Chem. Pathol. Pharmacol., 4, 657-697.

27. Mogenson, G.J., Jones, D.L., and Yim, C.Y. (1980): From motivation to action: functional interface between the limbic system and the motor system. Prog. Neurobiol., 14, 69-97.

28. Hornykiervicz, O. (1982): Brain catecholamines in schizophrenia-a good case for noradrenaline. Nature, 299, 484-486.

29. Blundell, J.E., Latham, C.J., and Leshem, M.B. (1976): Differences between the anorexic actions of amphetamine and fenfluramine: possible effects on hunger and satiety. J. Pharm. Pharmacol., 28, 471-477.

30. Leibowitz, S.F. (1975): Catecholaminergic mechanisms of the lateral hypothalamus: their role in the mediation of amphetamine anorexia. Brain Res., 98, 529-545.

31. Lytle, L.D. (1977): Control of eating behaviour, in Nutrition and the Brain, Vol. 2, ed. by Wurtman, R.J., and Wurtman, W.W., Raven Press, New Yrok, pp. 1-146.

32. Robinson, R.G., McHugg, P.R., and Folstein, M.S. (1975): Measurement of appetite disturbances in psychotic disorders. J. Psychiatr. Res., 12, 59-68.

33. Roberge, A.G. (1978): A morphological and biochemical dissociation between dopamine and serotonin in cat brain, in Catecholamines: Basic and Clinical Frontiers, ed. by Usdin, Kopin, and Barchas, Pergamon Press, New York, pp. 1110-1112.

34. Roberge, A.G., Parent, A., and Boulay, M. (1976): Démonstration d'une relation inversement proportionnelle entre la dopamine et la sérotonine dans certaines structures cérébrales: aspects neurochimique et morphologique. J. Neurochem., 26, 591-595.

35. Antelman, S.M., and Caggiula, A.R. (1977): Norepinephrine-dopamine interaction and behavior. Science, 195, 646-653.

36. Lo, C.W. (1986): A unitary view on the aetiology of schizophrenia. Br. J. Psychiatry, 149, 244-247.

37. Wise, C.O., and Stein, L. (1973): Dopamine- $\beta$-hydroxylase deficits in the brains of schizophrenic patients. Science, 181, 344-347.

38. Bird, E.D., Spokes, E.G., Barnes, J., Mackary, A.V.P., Iversen, L.L., and Shepard, M. (1977): Increased brain dopamine and reduced glutamic acid decarboxylase and choline acetyltransferase activity in schizophrenia and related psychoses. Lancet, 2, 1157-1159.

39. Crow, T.J., Owen, F., Cross, A.J., Lofthouse, R., and Longden, A. (1978): Brain biochemistry in schizophrenia. Lancet, 1, 36-37.

40. Crow, T.J., Baker, H.F., Cross, A.J., Joseph, M.H., Lofthouse, R., Longden, A., Owen, F., Riley, G.J., Glover, V., and Killpack, W.S. (1979): Monoamine mechanisms in chronic schizophrenia: postmortem neurochemical findings. Br. J. Psychiatry, 134, 249-256.

41. Anden, N.E., Dahlstrom, A., Fuxe, F., and Larsson, K. (1965): Further evidence for the presence of nigroneostriatal dopamine neurons in the rat. Am. J. Anat., 116, 329-333.

42. Moore, R.Y. (1980): The reticular formation: monoamine neuron systems, in The Reticular Formation Revisited, ed. by Hobson, J.A., and Brazier, M.A.B., Raven Press, New Yrok, pp. 67-81.

43. Barnes, D.M. (1987): Biological issues in schizophrenia. Science, 235, 430-433.

44. Curzon, G., and Sarna, G.S. (1984): Tryptophan transport to the brain: newer findings and older ones reconsidered, in Progress in Tryptophan and Serotonin Research, ed. by Schlossberger, H.G., Kochen, W., Linzen, B., and Steinhart, H., Walter de Gruyter, New Yrok, pp. 145-160. 
45. Heroux, O., and Roberge, A.G. (1981): Different influences of the two types of diets commonly used for rats on a series of parameters related to the metabolism of central serotonin and noradrenaline. Can. J. Physiol. Pharmacol., 59, 108-112.

46. Joseph, M.H., Johnson, J.A., and Kennett, G.A. (1984): Increased availability of tryptophan to the brain in stress is not mediated via changes in competing amino acids, in Progress in Tryptophan and Serotonin Research, ed. by Schlossberger, H.G., Kochen, W., Linzen, B., and Steinhart, H., Walter de Gruyter, New York, pp. 387-396.

47. Shuster, E.M., and Bodwell, C.E. (1979): Relationship between protein nutritional value as estimated in young men and rats, essential amino acid composition and protein digestibility. Fed. Proc., 38, 284-291.

48. Henry, K.M., and Toothill, J.A. (1962): A comparison of the body-water and nitrogen balance-sheets methods for determining the nutritive value of proteins. Br. J. Nutr., 16, 125133.

49. Thibault, L., and Roberge, A.G. (1987): Dietary protein and carbohydrate effects on blood parameters related to stress in cat. Physiol. Behav., 42, 1-5.

50. Thibault, L., and Roberge, A.G. (1987): Dietary protein-induced changes in serum dopamine$\beta$-hydroxylase activity, glucose, insulin, cortisol and pyridoxal-5' phosphate levels in normal and immobilized cats. J. Clin. Biochem. Nutr., 3, 55-64.

51. Ross-Smith, P., and Jenner, F.A. (1980): Diet (gluten) and schizophrenia. $J$. Nutr., 34, 107112. 